\title{
PENGEMBANGAN LEMBAR AKTIVITAS SISWA (LAS) MENGGUNAKAN PENDEKATAN DIFFERENTIATED INSTRUCTION UNTUK MENINGKATKAN KEMAMPUAN PEMECAHAN MASALAH MATEMATIS SISWA SMK
}

\author{
Ade Evi Fatimah ${ }^{1}$, Azrina Purba ${ }^{2}$ \\ ${ }^{1,2}$ Program Studi Pendidikan Matematika STKIP Pelita Bangsa Binjai \\ 1eviade997@gmail.com, ${ }^{2}$ azrinapur@gmail.com
}

\begin{abstract}
The purpose of this study is to produce quality student activity sheets. To achieve this, this research uses development research. The development model used in this study is a 4-D development model consisting of the Define, Design, Development and Disseminate stages. The subject of this research is the tenth grade students of SMK 1 Percut Sei Tuan Deli Serdang Regency and the object of this research is the mathematics student activity sheet of trigonometry material using the Differentiated Instruction (DI) approach. Developed in this study is the student activity sheet (LAS). The results of the study show that: (1) the level of mastery learning in classical is $83.33 \%$; (2) the level of student activity during the learning process takes place on the ideal time tolerance criteria; (3) the level of the teacher's ability to manage learning is good, because the average has reached the minimum criteria; (4) student responses to the components of the device and the learning process are positive; (5) Mathematical problem solving abilities of students have increased with an average value of 1.457 at pretest and 3.103 in postes with an average increase ( $N$ Gain) included in the medium category with an average of 0.521. The researcher suggested that the Differentiated Instruction approach be an alternative for teachers to improve students' mathematical problem solving abilities.
\end{abstract}

Keywords: Student Activity Sheet, Differentiated Instruction Approach, mathematical problem solving ability

\begin{abstract}
Abstrak. Tujuan penelitian ini adalah untuk menghasilkan lembar aktivitas siswa yang berkualitas. Untuk mencapai itu, penelitian ini menggunakan penelitian pengembangan. Model pengembangan yang digunakan dalam penelitian ini adalah model pengembangan 4-D yang terdiri dari tahap Define (Pendefinisian), Design (perancangan), Develop (pengembangan) dan Disseminate (penyebaran). Subjek penelitian ini adalah siswa kelas X SMKN 1 Percut Sei Tuan Kabupaten Deli Serdang dan objek penelitian ini adalah lembar aktivitas siswa matematika materi trigonometri dengan menggunakan pendekatan Differentiated Instruction (DI). Yang dikembangkan pada penelitian ini adalah lembar aktivitas siswa (LAS). Hasil penelitian menunjukkan bahwa: (1) tingkat ketuntasan belajar secara klasikal sebesar 83,33\%; (2) kadar aktivitas siswa selama proses pembelajaran berlangsung berada pada kriteria batas toleransi waktu ideal; (3) tingkat kemampuan guru dalam mengelola pembelajaran sudah baik, karena rata-ratanya telah mencapai kriteria minimal; (4) respon siswa terhadap komponen-komponen perangkat dan proses pembelajaran adalah positif; (5) Kemampuan pemecahan masalah matematis siswa mengalami peningkatan dengan nilai rata-rata 1,457 pada pretes dan 3,103 pada postes dengan rataan peningkatan (N Gain ) termasuk dalam kategori sedang dengan ratarata 0,521. Peneliti memberikan saran agar pendekatan Differentiated Instruction menjadi alternatif bagi guru dalam meningkatkan kemampuan pemecahan masalah matematis siswa.
\end{abstract}

Kata Kunci: lembar aktivitas siswa, pendekatan differentiated instruction, kemampuan pemecahan masalah matematis

\section{PENDAHULUAN}

Dalam sistem pendidikan, peserta didik merupakan subyek yang menjadi fokus utama. Seharusnya para pendidik menfokuskan keberhasilan dan kualitas para peserta didiknya. Berkenaan dengan hal tersebut di atas, salah satu pelajaran yang penting dalam menunjang peningkatan kualitas para peserta didik yaitu pelajaran matematika. Guru 
sebagai tenaga pendidik tetap harus berpikir keras bagaimana mengemas materi pelajaran matematika agar menjadi menarik dan mudah dipahami oleh siswa.

Dalam pembelajaran matematika, siswa-siswa dihadapkan pada masalah-masalah. Untuk itu siswa harus dibekali dengan keterampilan memecahkan masalah tersebut. Menurut Cooney seperti yang dikutip oleh Hudojo (2005:130) bahwa mengajar siswa menyelesaikan masalah-masalah memungkinkan siswa itu menjadi analitik dalam mengambil keputusan. Dengan kata lain, jika seorang siswa dilatih untuk menyelesaikan masalah, maka siswa itu akan mampu mengambil keputusan sebab siswa itu mempunyai keterampilan tentang bagaimana mengumpulkan informasi yang relevan, menganalisis informasi dan menyadari betapa perlunya meneliti kembali hasil yang diperolehnya.

Pentingnya kemampuan pemecahan masalah bagi peserta didik, terlihat dari ditentukannya standar untuk kemampuan tersebut. Standar kemampuan pemecahan masalah tersebut tertulis dalam NCTM (2000:334) yang merumuskan tentang standar pemecahan masalah sebagai berikut:

"Instructional programs from prekindergarten through grade 12 should enable all students to-: (1)Build new mathematical knowledge through problem solving;

(2) Solve problems that arise in mathematics and in other contexts; (3) Apply and adapt a variety of appropriate strategies to solve problems; (4) Monitor and reflect on process of mathematical problem solving"

Pernyataan di atas menunjukkan bahwa pembelajaran matematika harusnya memungkinkan siswa membangun pengetahuan yang baru melalui pemecahan masalah, menyelesaikan masalah yang muncul dari matematika atau dalam konteks lain, menerapkan dan mengadaptasi berbagai pendekatan dan strategi yang sesuai untuk menyelesaikan masalah dan memonitor serta merefleksi pada proses pemecahan masalah matematis.

Namun, kenyataan saat ini menunjukkan bahwa pencapaian siswa pada pelajaran matematika tergolong rendah dan belum memenuhi harapan. Hal ini diindikasikan dengan rendahnya hasil belajar siswa begitu juga dengan kemampuan pemecahan masalah matematis siswa.

Berkaitan dengan hal di atas dilakukan studi pendahuluan pada SMKN 1 Percut Sei Tuan dan diperoleh hasil bahwa siswa lebih cenderung pasif dalam kegiatan belajar, pembelajaran masih didominasi guru, siswa hanya menerima apa yang disampaikan oleh guru. Sehingga siswa kurang diberi kesempatan untuk membangun ide-ide dan pengetahuan yang mereka miliki. Ini berbeda jauh dengan yang diharapkan pada kurikulum 2013 yaitu, siswa dituntut untuk membangun pengetahuannya sendiri melalui investigasi, siswa juga dituntut untuk dapat menemukan sendiri penyelesaian dari masalah. Peran guru hanyalah sebagai fasilitator bukan penyedia sumber informasi.

Untuk memperkuat alasan, maka diberikan tes pada siswa untuk mengukur kemampuan pemecahan masalah materi Trigonometri di kelas XI SP dan XI GBR1. Adapun tes tersebut yaitu: "Eko mengukur bayangan sebuah tiang di tanah. Setelah diukur, panjangnya mencapai $5 \mathrm{~m}$. Kemudian, ia mengukur sudut yang terbentuk antara ujung bayangan dengan ujung tiang. Besar sudut tersebut adalah $60^{\circ}$. Tanpa mengukur langsung tiang tersebut, dapatkah Eko menentukan tinggi tiang sebenarnya? Jika ya, coba kamu tentukan tinggi tiang tersebut". Hasil yang diperoleh menunjukkan bahwa masih banyak siswa yang belum mampu menyelesaikan soal dengan benar.

Selain fakta di atas faktor lainnya adalah belum tersedianya sumber belajar seperti perangkat dan bahan ajar yang mampu menumbuh kembangkan kemampuan pemecahan masalah matematis siswa. Amri (2013:59) mengungkapkan mengapa bahan ajar perlu untuk dikembangkan karena bahan pembelajaran menempati posisi yang sangat penting dari keseluruhan kurikulum, yang harus dipersiapkan agar pelaksanaan pembelajaran dapat mencapai sasaran. 
Seperti yang kita ketahui LKS yang diterbitkan/diedarkan oleh instanti tertentu belum mencerminkan LKS yang semestinya. Seperti yang diungkapkan Amri (2013:97) jika mutu buku tidak memenuhi standar mutu, terutama dalam kaitannya dengan konsep dan aplikasi konsep (miskonsepsi, bahkan salah konsep), buku tersebut menjadi sumber pembodohan, bukan sumber pencerdasan anak didik. Buku demikian sangat berbahaya bagi dunia pendidikan. Sama halnya dengan instrumen tes yang diberikan guru juga belum memadai. Selama ini instrumen tes yang diberikan guru belum mengarahkan siswa dalam menyelesaikan masalah. Ini belum sesuai dengan yang diharapkan. Sehingga perlu dilakukan perbaikan dengan mengembangkan sebuah tes yang mampu mengarahkan siswa untuk menyelesaikan masalah matematis.

Faktor lain yang mempengaruhi rendahnya tingkat kemampuan matematika siswa adalah cara mengajar guru yang kurang efektif. Guru harus mampu memilih pembelajaran yang sesuai bagi setiap siswa. Selain itu, guru perlu mempertimbangkan perbedaan individual siswa karena tidak semua siswa itu sama. Guru harus mengubah cara mengajar tradisional atau konvensional yang sering digunakan menuju bentuk pengajaran yang dapat mengakomodir perbedaan-perbedaan individual tersebut. Karena Tomlinson dan Kalbfleisch (Wulandari dan Sagita, 2011:274) menyatakan bahwa mengabaikan perbedaan karakteristik siswa dapat mengakibatkan siswa kehilangan motivasi dan gagal untuk berhasil.

Menimbang keutamaan mengatasi perbedaan individual siswa yang telah diuraikan di atas maka diperlukan suatu cara atau pendekatan yang dapat mengatasi permasalahan perbedaan individual yaitu dengan membedakan instruksi (differentiated instruction). Differentiated Instruction (DI) adalah cara untuk menyesuaikan instruksi kepada kebutuhan siswa dengan tujuan memaksimalkan potensi masing-masing siswa dalam lingkup yang diberikan. DI memberikan kesempatan yang lebih banyak kepada siswa untuk mengeksplorasi perbedaan individualnya untuk dijadikan kekuatan dalam memahami matematika. Proses tersebut diawali dengan pengumpulan informasi awal siswa berupa kesiapan belajar (readiness), minat (interest), dan gaya belajar (learning style) siswa pada tahap sebelum pembelajaran dimulai yang dilakukan guru.

Semua siswa tidaklah sama. Berdasarkan hal inilah DI diberlakukan di dalam kelas yang heterogen agar siswa memiliki beberapa pilihan untuk memperoleh informasi dan menghasilkan berbagai ide. Pendekatan DI mengharuskan para guru untuk menjadi fleksibel dalam pendekatan mereka ketika mengajar, menyesuaikan kurikulum, dan menyajikan informasi kepada siswa. DI merupakan teori pengajaran yang didasarkan pada pernyataan bahwa pendekatan pembelajaran yang digunakan harus bervariasi dan disesuaikan dengan kebutuhan masing-masing siswa.

Hall (2002: 2) menyatakan bahwa "To differentiate instruction is to recognize students varying background knowledge, readiness, language, preferences in learning, interests, and to react responsively. Differentiated instruction is a process to approach teaching and learning for students of differing abilities in the same class. The intent of differentiating instruction is to maximize each student's growth and individual success by meeting each student where he or she is, and assisting in the learning process."

Menurut Hall membedakan pembelajaran dalam DI adalah untuk mengenali siswa yang berbeda dalam latar belakang pengetahuan, kesiapan, bahasa, minat belajar, gaya belajar. DI merupakan proses pengajaran yang digunakan dalam pembelajaran bagi siswa yang memiliki kemampuan berbeda di dalam kelas yang sama. Maksud dari DI adalah untuk memaksimalkan pertumbuhan dan keberhasilan masing-masing siswa dengan menemui setiap siswa dimanapun dia berada dan membantunya dalam proses pembelajaran. 
Kondisi di atas yang menjadi alasan mengapa penulis mengembangkan lembar aktivitas siswa (LAS) dengan menggunakan pendekatan DI. Sebuah LAS yang dapat menumbuhkembangkan kemampuan pemecahan masalah matematis siswa yang berkualitas seperti yang diungkapkan oleh Nieveen (2007:94) bahwa suatu bahan ajar maupun perangkat dikatakan berkualitas, jika memenuhi kriteria-kriteria antara lain; (1) Relevance (content validity); (2) Consistency (Construct validity); (3) kepraktisan (practicality); (4) keefektifan (effectiveness). Tanpa adanya bahan ajar seperti LAS akan sulit bagi guru untuk meningkatkan efektivitas pembelajaran. Begitu juga halnya dengan siswa, tanpa bahan ajar siswa akan mengalami kesulitan untuk menyesuaikan diri dalam belajar

Berdasarkan latar belakang di atas, maka dalam penelitian ini permasalahan yang dikemukakan adalah: (1) Apakah lembar aktivitas siswa materi trigonometri yang dikembangkan valid; (2) Apakah lembar aktivitas siswa materi trigonometri yang dikembangkan praktis; (3) Apakah pembelajaran yang menggunakan lembar aktivitas siswa yang dikembangkan efektif; dan (4) Bagaimana peningkatan kemampuan pemecahan masalah matematis siswa.

\section{METODE}

Penelitian ini merupakan penelitian pengembangan. Penelitian pengembangan yang dilaksanakan di SMKN 1 Percut Sei Tuan ini adalah pengembangan sebuah lembar aktivitas siswa (LAS) materi trigonometri menggunakan pembelajaran pendekatan Differentiated Instruction untuk meningkatkan kemampuan pemecahan masalah matematis siswa SMK kelas X. Adapun yang dikembangkan pada penelitian ini meliputi LAS, serta instrumen tes kemampuan pemecahan masalah matematis. Tujuan penelitian ini adalah menghasilkan LAS yang valid, praktis dan efektif untuk pembelajaran. Model pengembangan yang digunakan adalah dengan memodifikasi model 4-D (Four D model) dari Thiagarajan (1974:5-9) yang terdiri dari empat tahap, yaitu: (1) tahap pendefinisian (Define); (2) tahap perancangan (Design); (3) tahap pengembangan (develop); (4) tahap penyebaran (disseminate). Untuk tahap keempat yaitu pengembangan tidak dilakukan karena keterbatasan waktu. Instrumen yang digunakan pada penelitian ini adalah lembar validasi LAS, lembar observasi kegiatan guru dan siswa, lembar angket respon siswa serta tes kemampuan pemecahan masalah matematis siswa.

\section{HASIL DAN PEMBAHASAN}

Untuk menghasilkan lembar aktivitas siswa (LAS) yang berkualitas harus memenuhi kriteria valid, praktis dan efektif, peneliti mengikuti prosedur pengembangan LAS dan menganalisis data hasil penelitian. Terlebih dahulu dilakukan pengembangan dengan menggunakan modifikasi model 4-D.

Untuk tahap pendefinisian dimulai dari kegiatan analisis awal-akhir yang memiliki tujuan untuk mengidentifikasi masalah dasar pada topik trigonometri dengan melakukan investigasi awal terhadap proses pembelajaran selama ini, kemampuan matematis siswa, materi dan kurikulum yang berlaku. Pada pembelajaran materi trigonometri terutama penerapannya pada kemampuan pemecahan masalah, siswa diarahkan pada pemahaman masalah. Membuat model matematis, diberikan waktu untuk memilih strategi apa yang tepat serta menyelesaikan masalah tersebut dengan caranya sendiri. Pendekatan Differentiated Instruction diberikan untuk lebih memudahkan siswa dalam menyelesaikan masalah.

Sebelum diberikan perlakuan terlebih dahulu dilakukan analisis siswa kelas X SMKN 1 Percut Sei Tuan. Dalam pembelajaran matematika sangat cocok jika pembelajaran diawali dengan masalah dalam kehidupan nyata yang dialami oleh siswa secara langsung. 
Penyusunannya diawali dari yang konkret sampai yang abstrak sehingga dapat membantu siswa.

Untuk analisis materi dilakukan sebelum penyusunan LAS dan pelaksanaan pembelajaran. Agar materi yang disajikan terstruktur dan sistematis. Sedangkan analisis tugas disesuaikan dengan analisis materi.

Analisis tugas untuk materi trigonometri disusun merujuk pada indikator ketercapaian dan indikator kemampuan pemecahan masalah yang termuat dalam kisi-kisi penyusunan tes kemampuan pemecahan masalah. Selanjutnya pemilihan format, tahapan ini bertujuan untuk memilih format yang sesuai dengan faktor-faktor yang telah dijabarkan dalam kompetensi dasar, yaitu format untuk mendesain isi pembelajaran yang mengacu pada hasil analisis materi, analisis tugas dan indikator hasil belajar yang telah dirumuskan.

Selanjutnya tahap kedua yaitu tahap perancangan diawali dengan penyusunan tes. Tes disusun berdasarkan indikator ketercapaian dan indikator kemampuan pemecahan masalah matematis. Tahap pengembangan dimulai dengan validasi ahli. Ini dilakukan untuk mengetahui validitas isi dari draf 1 yang telah dirancang. Rekapitulasi hasil validasi perangkat dapat dilihat pada tabel 1 .

Tabel 1. Rekapitulasi nilai hasil validasi perangkat

\begin{tabular}{cccc}
\cline { 2 - 3 } No & Validator & LAS & TKPM \\
\hline 1 & I & 4,53 & Baik, dapat digunakan dengan sedikit revisi \\
2 & II & 4,47 & Baik, dapat digunakan dengan sedikit revisi \\
3 & III & 4,47 & Baik, dapat digunakan dengan sedikit revisi \\
\hline \multicolumn{2}{r}{ Skor rata-rata } & 4,49 & \\
\hline
\end{tabular}

Dari tabel 1 dapat kita lihat skor rata-rata akhir penilaian validator terhadap LAS draf 1, yaitu 4,49 yang berarti draf 1 LAS termasuk dalam kategori baik. Sedangkan kesimpulan yang diberikan adalah dapat digunakan dengan sedikit revisi. Sedangkan untuk tes kemampuan pemecahan masalah matematis ketiga validator menyatakan valid meskipun ada revisi sedikit pada bahasa yang digunakan. Berdasarkan hasil validasi ahli terhadap LAS dan isntrumen tes kemampuan pemecahan masalah matematis dapat disimpulkan bahwa LAS yang dikembangkan telah memenuhi kriteria valid. Sebelum ujicoba lapangan maka dilakukan ujicoba terbatas pada siswa untuk melihat apakah LAS sudah bisa diterapkan di lapangan. Dari hasil yang diperoleh LAS dan isntrumen tes sudah bisa digunakan dengan sedikit revisi.

Selanjutnya dilakukan ujicoba lapangan untuk mengetahui kriteria kepraktisan dan keefektifan lembar aktivitas siswa (LAS). Kriteria kepraktisan berdasarkan penilaian validator yang menyatakan bahwa LAS ini praktis untuk digunakan dan hasil ujicoba lapangan dimana semua siswa dapat menggunakan LAS dengan baik melalui observasi aktivitas siswa. Berdasarkan hasil penelitian tersebut maka dapat dikatakan bahwa LAS yang dihasilkan memenuhi kriteria praktis. Setelah kriteria valid dan praktis terpenuhi maka selanjutnya kita akan lihat keefektifan pendekatan Differentiated Instruction dengan menggunakan LAS yang dikembangkan. Kriteria efektif dilihat dari 4 hal, yaitu:

1. kemampuan pemecahan masalah matematis siswa pada hasil pretes uji coba lapangan diperoleh bahwa jumlah siswa yang tuntas ada sebanyak 6 orang dari 30 orang siswa (20\%). Jumlah siswa yang tidak tuntas ada sebanyak 24 orang dari 30 orang siswa (80\%). Setelah dilakukan pendekatan Differentiated Instruction dengan menggunakan LAS, diperoleh bahwa banyaknya siswa yang tuntas adalah 25 orang dari 30 orang siswa $(83,33 \%)$. Banyak siswa yang tidak tuntas adalah 5 orang dari 30 orang siswa (16,67\%). Sehingga berdasarkan kriteria yang ditetapkan pada kurikulum 2013 bahwa secara klasikal suatu pembelajaran dikatakan telah tuntas jika terdapat $75 \%$ siswa yang 
mengikuti tes telah mencapai skor minimal 2,66. Berdasarkan penjelasan di atas ketuntasan belajar siswa pada pretes adalah $20 \%$ dan postes adalah sebesar $83,33 \%$, sehingga ketuntasan belajar siswa pada penelitian terjadi peningkatan. Rekapitulasi ketuntasan kemampuan pemecahan masalah matematis siswa disajikan pada tabel 2.

Tabel 2. Rekapitulasi Ketuntasan Kemampuan Pemecahan Masalah Matematis Siswa

\begin{tabular}{ccccc}
\hline \multirow{2}{*}{ Kategori } & \multicolumn{2}{c}{ Pretes } & \multicolumn{2}{c}{ Postes } \\
\cline { 2 - 5 } & Jumlah Siswa & Persentase & Jumlah Siswa & Persentase \\
\hline Tuntas & 6 orang & $20 \%$ & 25 orang & $83,33 \%$ \\
\hline Tidak tuntas & 24 orang & $80 \%$ & 5 orang & $16,67 \%$ \\
\hline Jumlah & 30 orang & $100 \%$ & 30 orang & $100 \%$ \\
\hline
\end{tabular}

2. Pencapaian waktu ideal aktivitas siswa, pada penelitian ini persentase kadar aktivitas siswa yang diperoleh selama proses pembelajaran masih dalam batas toleransi waktu ideal. yaitu: (a) waktu yang digunakan untuk kegiatan mendengarkan/memperhatikan penjelasan guru/teman sebesar 15,875\% dari waktu yang tersedia; (b) waktu yang digunakan untuk kegiatan membaca/ memahami masalah kontekstual di buku siswa/LAS sebesar 19,625\% dari waktu yang tersedia; (c) waktu yang digunakan untuk kegiatan menyelesaikan masalah/ menemukan penyelesaian dan jawaban masalah sebesar 37,375\% dari waktu yang tersedia; (d) waktu yang digunakan untuk kegiatan berdiskusi/bertanya antar siswa atau guru sebesar 25,2\% dari waktu yang tersedia; (e) waktu yang digunakan untuk perilaku yang tidak relevan dengan KBM 1,625\% dari waktu yang tersedia dan masih dalam batas toleransi waktu ideal. Berdasarkan data hasil pengamatan tentang aktivitas siswa, terlihat bahwa kegiatan menyelesaikan masalah/ menemukan penyelesaian dan jawaban merupakan aktivitas yang paling tinggi, maka ini menunjukkan bahwa LAS dengan pendekatan Differentiated Instruction dapat mengaktifkan siswa;

Kemampuan guru mengelola pembelajaran, berdasarkan hasil pengamatan diperoleh hasil bahwa kemampuan guru dalam mengelola pembelajaran sudah tergolong baik pada ujicoba lapangan sebesar 3,61. Dengan demikian kemampuan guru mengelola pembelajaran sudah memenuhi kriteria efektif

3. Respon siswa terhadap komponen dan proses pembelajaran. Pada ujicoba lapangan respon positif siswa baik yaitu sebesar $85,02 \%$. Ini menunjukkan LAS yang disusun dengan menggunakan pendekatan Differentiated Instruction mendapat respon yang baik. Siswa merasa senang dan tertarik terhadap komponen lembar aktivitas siswa.

Karena keempat indikator keefektifan pembelajaran sudah terpenuhi maka kriteria keefektifan pendekatan Differentiated Instruction dengan menggunakan LAS yang dikembangkan sudah terpenuhi.

\section{Kemampuan Pemecahan Masalah Matematis Siswa}

Kemampuan pemecahan masalah diukur berdasarkan tiga proses penemuan jawaban siswa, yaitu: (1) Membuat model matematis yang berhubungan dengan masalah dunia nyata; (2) Memilih strategi pemecahan masalah yang tepat untuk menyelesaikan model matematis tersebut; (3) Menjelaskan jawaban dan memeriksa kebenarannya. Jawaban yang diberikan siswa dalam memecahkan masalah akan diberikan skor sesuai dengan rubrik penskoran untuk setiap indikator yang dibuat.

Berdasarkan data hasil pretes dan postes, dapat dikatakan bahwa terjadi peningkatan kemampuan pemecahan masalah siswa. Peningkatan kemampuan pemecahan masalah siswa dapat dilihat dari nilai rataan tes, yaitu mulai dari rataan skor pretes sebesar 1,457 sedangkan rataan skor postes sebesar 3,103. Hal ini menunjukkan bahwa LAS dengan menggunakan pendekatan Differentiated Instruction yang dikembangkan dapat 
meningkatkan kemampuan pemecahan masalah matematis siswa dan besar peningkatan tersebut adalah 1,646.

Jika kita perhatikan berdasarkan masing-masing aspek maka rerata nilai pretes untuk aspek membuat model matematis memperoleh rata-rata sebesar 8,033, aspek memilih strategi yang tepat untuk menyelesaikan model matematis memperoleh rata-rata sebesar 5,467 , aspek memeriksa dan menjelaskan jawaban sebesar 1,1. Setelah perlakuan diberikan pada siswa, yaitu dengan menggunakan pendekatan Differentiated Instruction terdapat peningkatan kemampuan pemecahan masalah matematis. Berdasarkan hasil penelitian, rata-rata skor gain ternormalisasi kemampuan pemecahan masalah matematis siswa untuk setiap aspek adalah pada aspek membuat model matematis sebesar 0,469, aspek memilih strategi yang tepat untuk menyelesaikan model matematis sebesar 0,523, dan aspek memeriksa dan menjelaskan jawaban sebesar 0,44. Dan data hasil tes kemampuan pemecahan masalah siswa dengan perolehan rataan peningkatan $(N$-Gain) untuk keseluruhan aspek termasuk dalam kategori sedang dengan rata-rata 0,652. Peningkatan ini terjadi karena terdapat kesesuaian antara materi yang dikembangkan dengan pembelajaran yang dilakukan guru. Sehingga membuat siswa termotivasi dan tertarik untuk mempelajari materi tersebut yang mengakibatkan kemampuan pemecahan masalah siswa dapat meningkat.

Dari hasil yang diperoleh dapat kita ketahui bahwa peningkatan kemampuan pemecahan masalah yang paling tinggi adalah pada aspek memilih strategi yang tepat untuk menyelesaikan model matematis. Salah satu faktor yang mendukung terjadinya peningkatan ini adalah proses pembelajaran yang dilakukan yaitu melalui pendekatan Differentiated Instruction (DI). Pendekatan DI merupakan cara untuk menyesuaikan instruksi kepada kebutuhan siswa dengan tujuan memaksimalkan potensi masing-masing siswa dalam lingkup yang diberikan. DI merupakan suatu cara yang dapat digunakan untuk meningkatkan kemampuan pemecahan masalah matematis karena siswa diberikan pilihan pembelajaran dan dikelompokkan berdasarkan gaya belajar. Kelas yang diberikan pendekatan DI bekerja bagus dalam kelompok dan menuntut kerja yang lebih bermakna dan berbasis pada masalah. Dengan adanya kelompok siswa yang sama gaya belajarnya, mereka akan lebih leluasa dalam berkomunikasi dan bekerja sama. Dengan demikian proses tersebut akan mengembangkan kecakapan berpikir siswa baik diajarkan oleh guru secara langsung atau memadukannya dalam materi pelajaran sehingga kemampuan pemecahan masalah matematis siswa akan lebih meningkat.

Selain itu peningkatan kemampuan pemecahan masalah siswa dapat dilihat dari persentase pencapaian siswa terhadap kemampuan pemecahan masalah siswa. Peningkatan kemampuan pemecahan masalah siswa berdasarkan data nilai pretes dan postes yang paling tinggi adalah aspek memilih strategi yang tepat sebesar 50\%. Hal ini mengindikasikan bahwa kemampuan pemecahan masalah mengalami peningkatan khususnya pada aspek memilih strategi yang tepat.

\section{KESIMPULAN DAN SARAN \\ Kesimpulan}

Berdasarkan hasil analisis dan pembahasan penelitian pada ujicoba lembar aktivitas siswa (LAS) materi trigonometri dengan menerapkan pendekatan Differentiated Instruction untuk meningkatkan kemampuan pemecahan masalah matematis siswa, maka dikemukakan beberapa kesimpulan sebagai berikut:

1. Lembar aktivitas siswa (LAS) yang dikembangkan telah memenuhi kriteria valid berdasarkan hasil penilaian para ahli dan praktisi terhadap LAS. Ketiga validator telah memberikan penilaian. Hasil penilaian para ahli dan praktisi dianalisis dengan melihat nilai rata-rata dan tingkat kesepakatan penilaian para ahli melalui analisis statistika 
interater Berdasarkan hasil yang diperoleh maka dapat disimpulkan bahwa LAS sudah valid dan layak untuk digunakan.

2. Lembar aktivitas siswa (LAS) yang dikembangkan telah memenuhi kriteria kepraktisan, yaitu:

a. Hasil penilaian ahli dan praktisi (guru) yang menyatakan bahwa LAS yang dikembangkan sudah praktis atau dapat digunakan dengan sedikit revisi.

b. Guru dan siswa dapat menggunakan LAS ini dalam pembelajaran dengan baik berdasarkan hasil pengamatan aktivitas siswa.

3. Pembelajaran yang dilakukan selama ujicoba lapangan dengan menggunakan lembar aktivitas siswa (LAS) telah memenuhi kriteria efektif, adapun kriterianya yaitu:

a. Ketuntasan belajar siswa pada ujicoba lapangan yang dilakukan memperoleh hasil bahwa jumlah siswa yang tuntas ada sebanyak 25 orang dari 30 orang siswa $(83,33 \%)$. Ini berarti menunjukkan bahwa ketuntasan siswa secara klasikal telah tercapai.

b. Aktivitas siswa selama proses pembelajaran telah memenuhi batas toleransi waktu ideal yang ditentukan. Aktivitas menyelesaikan masalah dan berdiskusi merupakan aktivitas yang paling banyak dilakukan oleh siswa ini menunjukkan bahwa pendekatan Differentiated Instruction mampu mengaktifkan siswa.

c. Kemampuan guru mengelola pembelajaran sudah memenuhi kriteria pada ujicoba lapangan, dengan nilai kemampuan guru (NKG) sebesar 3,61.

d. Respons siswa terhadap komponen dan proses pembelajaran tergolong respon yang positif. Respon positif ini diberikan pada ujicoba lapangan.

4. Terdapat peningkatan kemampuan pemecahan masalah matematis siswa yang menggunakan lembar aktivitas siswa (LAS) yang dikembangkan, terlihat dari rataan skor siswa pada saat pretes sebesar 1,457 menjadi 3,103 pada saat postes. Dan aspek kemampuan pemecahan masalah yang dimiliki siswa paling tinggi ada pada aspek memilih strategi yang tepat dengan rata-rata skor $N$-Gain sebesar 0,523. Peningkatan secara keseluruhan aspek yang terjadi diklasifikasikan dan termasuk dalam kategori Saran sedang dengan rataan $\mathrm{N}$-Gain sebesar 0,652 .

Berdasarkan kesimpulan penelitian di atas, maka penulis memberikan beberapa saran sebagai berikut:

1. Guru dapat mengembangkan lembar aktivitas siswa (LAS) dengan pendekatan Differentiated Instruction pada materi lainnya dalam memenuhi kebutuhan siswa terhadap sumber belajar yang memenuhi kriteria valid, praktis dan efektif.

2. Guru hendaknya menjadikan pendekatan Differentiated Instruction sebagai salah satu alternatif pembelajaran untuk meningkatkan kemampuan pemecahan masalah matematis siswa serta mampu meningkatkan aktivitas siswa.

3. Lembar aktivitas siswa (LAS) yang dikembangkan hanya berhenti sampai tahap pengembangan saja, belum diimplementasikan pada sekolah-sekolah, disarankan kepada guru dan peneliti selanjutnya agar mengimplementasikan pada ruang lingkup yang lebih luas.

\section{DAFTAR PUSTAKA}

Amin. 2009. Pembelajaran Berdiferensiasi: Alternatif Pendekatan Pembelajaran Bagi Anak Berbakat. Edukasi, 1(1).

Amri, S. 2013. Pengembangan \& Model pembelajaran dalam Kurikulum 2013. Jakarta: Prestasi Pustaka.

Asmin. 2012. Pengukuran dan Penilaian Hasil Belajar dengan Analisis Klasik dan Modern. Medan: Larispa Indonesia. 
Ditasona, C. 2013. Penerapan Pendekatan Differentiated Instruction dalam Peningkatan Kemampuan Pemecahan Masalah dan Penalaran Matematis Siswa SMA. Tesis pada PPs UPI. Bandung: Tidak diterbitkan.

Hall. T. 2002. Differentiated Instruction: Effective Classroom Practices Report. National Center on Accessing the General Curriculum. Principals.in. [Online]. Tersedia http://www.principals.in/uploads/pdf/Instructional_Strategie/DI_Marching.pdf [13 September 2013]

Harta, I. 2011. Differentiated Instruction: What, Why, and How? Yogyakarta: SEAMEO for Qitep in Mathematics. Tidak Diterbitkan.

NCTM, 2000. Principles and standards for school mathematics. Reston, VA: NCTM.

Nieveen, N. 1997. Computer Support for Curriculum Developers: A study on potential of computer support in the domain of formative curriculum evaluation. Thesis University of twente: Enschede.

Polya, G. 1973. How to solve it:A new aspect of mathematics method. New Jersey: Princeton University Press.

Thiagarajan, S., Semmel, D., \& Semmel, M. 1974. Instructional Development for Teacher of Exceptional Children. A Source Book Bloomington: Indiana University

Trianto. 2009. Mendesain Model Pembeajaran Inovatif Progresif, Jakarta: Penerbit Kencana.

Wulandari, I. \& Sagita, L. 2011. Pembelajaran Matematis dengan Differentiated Instruction untuk Mengembangkan Karakter Positif Siswa. Seminar Nasional Matematis dan Pendidikan Matematis. ISBN: 978-979-16353-6-3. [Online]. Tersedia http://eprints.uny.ac.id/7380/1/p-25.pdf. [12 September 2013] 